\title{
Retention of women accountants: The interaction of job demands and job resources
}

\begin{tabular}{|c|c|}
\hline \multicolumn{2}{|c|}{$\begin{array}{l}\text { Authors: } \\
\text { Stella Ribeiro } \\
\text { Anita Bosch } \\
\text { Jurgen Becker }\end{array}$} \\
\hline \multicolumn{2}{|c|}{$\begin{array}{l}\text { Affiliations: } \\
{ }^{1} \text { Department of Accountancy, } \\
\text { University of Johannesburg, } \\
\text { South Africa }\end{array}$} \\
\hline \multicolumn{2}{|c|}{$\begin{array}{l}{ }^{2} \text { Department of Industrial } \\
\text { Psychology and People } \\
\text { Management, University of } \\
\text { Johannesburg, South Africa }\end{array}$} \\
\hline \multicolumn{2}{|c|}{$\begin{array}{l}\text { Corresponding author: } \\
\text { Anita Bosch, } \\
\text { anitab@uj.ac.za }\end{array}$} \\
\hline \multicolumn{2}{|c|}{$\begin{array}{l}\text { Dates: } \\
\text { Received: } 02 \text { Oct. } 2015 \\
\text { Accepted: } 27 \text { Jan. } 2016 \\
\text { Published: } 26 \text { May } 2016\end{array}$} \\
\hline \multicolumn{2}{|c|}{$\begin{array}{l}\text { How to cite this article: } \\
\text { Ribeiro, S., Bosch, A., \& } \\
\text { Becker, J. (2016). Retention of } \\
\text { women accountants: The } \\
\text { interaction of job demands } \\
\text { and job resources. SA Journal } \\
\text { of Human Resource } \\
\text { Management/SA Tydskrif vir } \\
\text { Menslikehulpbronbestuur, } \\
\text { 14(1), a } 759 . \text { http://dx.doi. } \\
\text { org/10.4102/sajhrm. } \\
\text { v14i1.759 }\end{array}$} \\
\hline \multicolumn{2}{|c|}{$\begin{array}{l}\text { Copyright: } \\
\text { (C) 2016. The Authors. } \\
\text { Licensee: AOSIS. This work } \\
\text { is licensed under the } \\
\text { Creative Commons } \\
\text { Attribution License. }\end{array}$} \\
\hline \multicolumn{2}{|l|}{ Read online: } \\
\hline 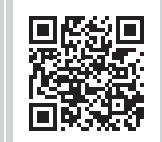 & $\begin{array}{l}\text { Scan this QR } \\
\text { code with your } \\
\text { smart phone or } \\
\text { mobile device } \\
\text { to read online. }\end{array}$ \\
\hline
\end{tabular}

Orientation: Most CEOs in South Africa are chartered accountants (CAs). Retaining women CAs might therefore lead to an increase in women in leadership. The Job Demands-Resources model presents a framework to investigate organisational job-related factors that promote or deter voluntary turnover of women CAs.

Research purpose: The primary objective was to investigate which organisational factors promote or reduce the risk of turnover intentions for South African women CAs. The secondary objective was to investigate the moderating potential of job resources on the relationship between job demands and turnover intentions.

Motivation for the study: There is a fair amount of research on the problems associated with the retention of women CAs in public practice but very little is known about how those problems interact with each other, and whether there are factors that could buffer them.

Research design, approach, and method: The study consisted of a sample $(n=851)$ of women CAs in public practice firms nationally in South Africa. We used structural equation modelling together with moderated regression analysis.

Main findings: Job demands promote turnover intentions, whereas job resources have a negative effect on turnover intentions. Counter-intuitively a negative direct effect was found between job insecurity and turnover intentions. Statistical support was found for the moderating role of all job resources, except financial advancement, on the relationship between work-family conflict and turnover intentions; and growth opportunities, on the relationship between job insecurity and turnover intentions.

Practical/managerial implications: No job resource measured could buffer the impact of job overload on turnover intentions.

Contribution: This is the first study to investigate factors that may retain women CAs in public practice audit, tax, and advisory firms (Big Four Accountancy Firms) using the JD-R model. Few studies have investigated the buffering effect of job resources on the relationship between job demands and turnover intentions in general.

\section{Introduction}

Significant changes in the global economic and social environment with underpinning legislation have resulted in public practice firms having to consider strategic ways to ensure the retention of women accountants. International research has shown for decades that more women graduates are entering the accountancy profession each year than men (Crosley, 2006; Gold, 2008a; Meredith \& French, 1996). However, two outcomes remain of concern. Firstly, a small percentage of women chartered accountants (CAs) remain employed in large public practice firms after completion of their trainee apprenticeships. An attrition rate of $56 \%$ immediately after completion of the training period is reported (South African Institute of Chartered Accountants [SAICA], 2009). Secondly, which is perhaps a knock-on effect of the first outcome, the percentage of women partners in accountancy public practice firms remains low (Crosley, 2006; Gold, 2008a, 2008b; Kornberger, Justesen \& Mouritsen, 2011).

Globally, a large amount of research has been conducted on the progression of the careers of women CAs, the obstacles they face, the reasons for their lack of progression into management positions, as well as their reasons for opting out of public practice. Most of the studies were conducted between the 1990s and late 2000s, and emerged primarily from the USA and the UK (refer to studies of Cabrera, 2007; Collins, 1993; Crosley, 2006; Gold, 2008a; Gold, 2008b; Haynes,

Note: This paper is an extension of reporting on the public reports titled: Women in the Workplace Research Report: Keeping South Africa's female chartered accountants in public practice. 
2008; Johnson, Lowe \& Reckers, 2008; Maitland, 2000; Meredith \& French, 1996), as well as a South African study by Sadler (1989), and more recent studies on Syrian women accountants (Kamla, 2012) and Mexican women accountants (Ruiz Castro, 2012).

Kornberger, Carter and Ross-Smith (2010) highlight that women are understudied in accounting and that interdisciplinary studies are needed to aid our understanding of the gender inequality phenomenon. Focusing more research efforts on the reasons why women CAs are not retained in public practice firms will only tell us more about the problems, but not provide information on how those problems interact with each other, and whether there are factors that could buffer these problems. Over the past three decades, various studies have endorsed the importance of job characteristics for employee well-being, work satisfaction, and performance (Bakker, Van Veldhoven \& Xanthopoulou, 2010; Deci \& Ryan, 1985; Mark \& Smith, 2008). Each occupation, such as that of accountants, has its own job characteristics, which can be broadly classified as either job demands or job resources (Bakker \& Derks, 2010; Demerouti, Bakker, De Jonge, Janssen \& Schaufeli, 2001a). The Job Demands-Resources (JD-R) model presents a framework that can be used to investigate organisational factors that promote or deter voluntary turnover of women CAs. The JD-R model was first introduced in 2001 (Demerouti, Bakker, Nachreiner \& Schaufeli, 2001b), and has been applied in studies across various professions as a predictor of employee well-being (Bakker, Demerouti \& Schaufeli, 2003a; Bakker, Demerouti \& Verbeke, 2004; Prieto, Soria, Martinez \& Schaufeli, 2008; Rothmann, Barkhuizen \& Tytherleigh, 2008; Rothmann \& Joubert, 2007; Schaufeli \& Bakker, 2004; Van den Berg, Manias \& Burger, 2008; Wiese, Rothmann \& Storm, 2003), and a predictor of work identity, as well as an indicator of employee turnover intentions (Bester, Roodt \& Bosch, 2012; De Braine \& Roodt, 2011).

To the purpose of more deeply understanding the interactions of demands and resources that have an impact on the work of women accountants, Minnotte's (2016, p. 416) application of the JD-R model found that 'results for mothers indicated that job resources and demands only mattered when the interactions between them were considered'. Therefore this study aimed to understand the job demands and job resources that contribute to turnover intentions often resulting in the low retention rates of women CAs and women trainee CAs in South African public practice audit, tax, and advisory firms. The primary objective of the study was to investigate, through the use of the JD-R model, which factors promote or reduce the risk of turnover intentions for South African women CAs. The secondary objective of the study was to investigate the moderating potential of job resources on the relationship between job demands and turnover intentions.

The study makes contributions in the following three ways: (1) firstly, this is the first study to investigate the impact of job demands and job resources on the turnover intentions of
South African women CAs in public practice audit, tax, and advisory firms; (2) secondly, the study will expand on which job demands and job resources correlate with turnover intentions for women accountants; and (3) lastly, few studies have investigated the buffering effect of job resources on the relationship between job demands and turnover intentions in general, and specifically with reference to women CAs working in public practice firms.

We commence with an overview of literature on the reasons for the low retention of women CAs where after we discuss the JD-R model with associated propositions. The method and results sections are followed by a discussion of the salient findings of our study.

\section{Reasons for low retention of women chartered accountants}

Many studies attribute the high turnover rate of women accountants to the male-dominated culture of professions such as accounting which, amongst others, does not allow for life cycle needs such as child bearing years, with resultant childcare (Barker \& Monks, 1998; Bell, 2009; Meredith \& French, 1996). The culture of accounting firms continues to resemble that of men (Barker \& Monks, 1998; Bosch, Ribeiro \& Becker, 2012). The ideal worker is therefore considered to be a man that is available $24 / 7$, and society's responsibility regarding children and other care roles are considered activities that occur beyond the boundaries of organisations (Lewis \& Humbert, 2010). Parental leave or flexible work hours are often seen as hindrances to productivity and steady workflow. Although conclusive research suggests that the lack of women's representation in public practice firms cannot be attributed to lack of commitment or ability (e.g. Barker \& Monks, 1998; Bell, 2009), women who have chosen to have children do seem to face care roles that differ greatly from those of their male counterparts. Work-family conflict therefore remains an area that is associated with the low retention of women accountants (Dambrin \& Lambert, 2008).

When considering non-essentialist views of women, other reasons that have been cited as possible causes for the low representation and, by implication, the high turnover of women accountants, include job overload and job insecurity. Job-related tension such as job overload and environmental stressors (Collins, 1993) contribute negatively to the retention of women accountants. The accounting profession is known for its long working hours, high volumes of work, and pressing deadlines (Gammie, Gammie, Matson \& Duncan, 2007; Ruiz Castro, 2012). 'Research has also shown that the prevalence of psychological distress is higher in those employees who are required to work more than $60 \mathrm{~h}$ per week (Hilton, 2008), which is not uncommon for accountants in public practice' (Bosch et al., 2012, p. 22). A 1998 study of Irish CAs revealed that most CAs in that sample were working $50-60 \mathrm{~h}$ per week, and that $82 \%$ of women in that study thought that success in an accountancy career meant working very long hours (Barker \& Monks, 1998). 
The commoditisation of time and global economic turbulence has led to employment trends such as layoffs, and increased temporary working arrangements which contribute to pronounced levels of job insecurity amongst accountants (Sweeny \& Quirin, 2009). In this climate, costing and budgetary control mechanisms, such as the use of unit labour costs, have been linked to a disproportionate increase in women in temporary positions, and their remuneration in this capacity is considerably lower than that of men (Armstrong, 2000).

Other reasons cited for the low retention of women accountants relate to a lack of growth and development opportunities. Some of these are mentorship and formal talent management (Gold, 2008b; Sadler, 1989); a lack of a sense of belonging to an organisation (Maitland, 2000; Sadler, 1989), which is also underscored by men and women accountants receiving differing levels of social support from their managers (Windsor \& Auyeung, 2006); women's lack of networking skills when compared to men (Crosley, 2006); a lack of opportunity for advancement (Barker \& Monks, 1998; Cabrera, 2007); and unequal remuneration and benefits (Barker \& Monks, 1998). The importance of team climate in countering the difficulties of diversity in teams, including gender diversity, is yet to be laid to rest, as studies reflect contradictory results (Tekleab \& Quigley, 2014). However, a positive team climate assists with the retention of women accountants. The external prestige of an accountancy organisation is furthermore said to retain both women and men through the promise of career growth opportunities (Nouri \& Parker, 2013).

The above cited reasons can be broadly categorised into either job demands or job resources, depending on how public practice firms structure and manipulate supportive and detractive characteristics of an accountant's job. In the current study three job demands and five job resources, as identified in the literature above, were deemed as critical to investigate voluntary turnover in the CA profession. The job demands included in the study are work-family conflict, job overload, and job insecurity. The job resources used in this study are: growth opportunities (variety, opportunities to learn, and job independence), social support (relationships with supervisors and colleagues), advancement (remuneration, career possibilities, and training opportunities), perceived organisational external prestige (image and reputation of a firm), and team climate (collaboration and trust in a team). In the following section, the JD-R model is described, and the relationships are explained.

\section{Theoretical framework: Job Demands-Resources model}

The JD-R model expands the job demands control model by underscoring the motivational role of job resources as antecedents to salutogenic work outcomes (e.g. work engagement and commitment) and buffering moderators in the job stress-strain process (Kain \& Jex, 2010; Schaufeli \& Bakker, 2003; Schaufeli \& Salanova, 2007).

The health impairment process is based on the notion that excessive job demands exhaust employees mentally and physically (Demerouti et al., 2001b; Hakanen \& Roodt, 2010). Furthermore, excessive job demands and health problems lead to absenteeism (Bakker, Demerouti, Taris, Schaufeli \& Schreurs, 2003b).

Job demands refer to 'physical, social, or organisational aspects of a job that require sustained physical and/or psychological effort on the part of the employee' (Bakker et al., 2004, p. 86; Schaufeli \& Bakker, 2004). Chartered accountants are often faced with demands for the delivery of work that is accurate and complex under high time- and volume pressure. Other demands include emotional strain, role ambiguity, lack of feedback, unfavourable working conditions and environments, and a lack of support from supervisors and colleagues (Bakker \& Demerouti, 2007; Schaufeli \& Bakker, 2004).

Job resources are those 'physical, psychological, social, or organisational aspects of a job that (a) reduce job demands and the associated physiological and psychological costs; (b) are functional in achieving work goals; and (c) stimulate personal growth, learning, and development' (Bakker \& Demerouti, 2007, p. 312). Turnover intentions are defined as the thought of quitting, the intention of searching for another job, and the 'employee's subjective assessment that they will leave their current occupation in the near future' (Carmeli \& Gefen, 2005, p. 70).

Job resources can be located at an 'organisational level (pay, opportunity, and security), an interpersonal level (team climate, supervisor support), an organisation of work level (role clarity and participation in decision-making), and at task level (skill variety, task significance, autonomy, and feedback)' (Bakker \& Demerouti, 2007; Demerouti \& Bakker, 2011, p. 4). As with job demands, women CAs have access to varying levels and types of job resources in public practice firms. 'Job resources play an intrinsic motivational role if they foster growth, learning, and development, or an extrinsic motivational role if they assist in achieving work goals' (Schaufeli \& Bakker, 2004, p. 298).

The literature suggests strong positive correlations between job resources and engagement. Similarly, studies have found that job resources such as coaching, feedback, and support predict dedication and commitment, which are strongly negatively correlated to turnover intentions (Bakker et al., 2003a; Bakker \& Demerouti, 2007). It has also been found that 'engagement mediates the relationship between job resources and turnover intentions' (Schaufeli \& Bakker, 2004, p. 299).

\section{Interaction of job demands and resources}

Despite the voluminous support found for the strong main effects of job demands and job resources on key wellness 
outcomes, relatively little research has been conducted on the moderating potential of job resources on the stressstrain sequence. Contributions by Xanthopoulou, Bakker, Demerouti and Schaufeli (2009) suggest that job resources can play a buffering role in the prevention of strain. It stands to reason then that job resources could moderate the relationship between job demands and turnover intentions. For example, feeling valued at work may reduce demands such as job overload. By the same token, good communication with employees and constructive feedback improve effectiveness (Bakker \& Demerouti, 2007). Therefore, we would expect job resources to buffer the adverse impact of job demands on turnover intentions.

The above leads us to propose a complex theoretical model predicting turnover intentions of women CAs in public practice, based on the relationship between the constructs of the JD-R model as illustrated in Figure 1. The three job demands of job overload, work-family conflict, and job insecurity are predicted to promote higher levels of turnover intentions. The job resources of growth opportunities, social support, advancement, organisational prestige, and team climate are expected to have negative associations with turnover intentions. Moreover, job resources (combined and individually) are expected to buffer the relationship between job demands and turnover intentions.

The following section explains the research design that was used to empirically operationalise and test the proposed theoretical model.

\section{Method}

\section{Procedure and participants}

The SAICA database was utilised to contact trainee (those women graduate CAs in apprenticeships) and qualified women CAs across South Africa to participate in the research project. In total 7228 questionnaires were distributed: 1989 to qualified women CAs, and 5239 to women trainee CAs in South African public practice firms.

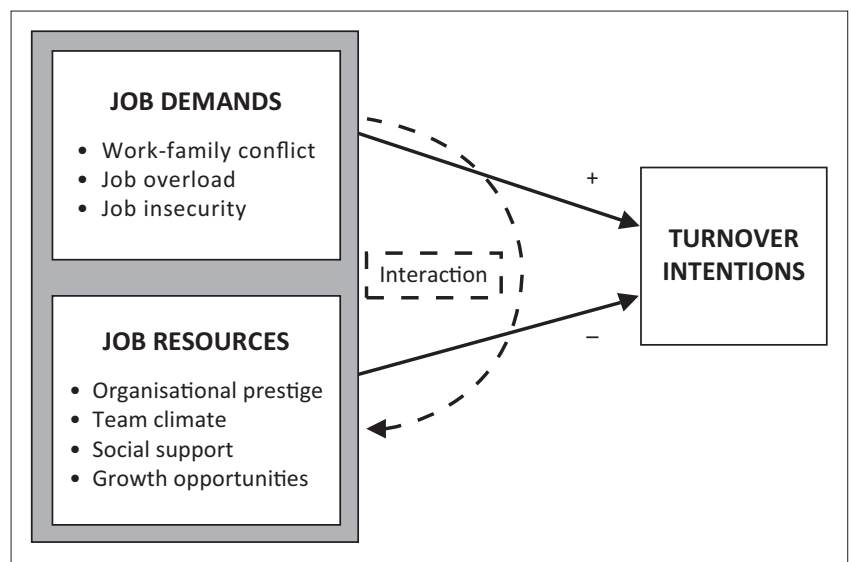

Source: Adapted from Procopiou Ribeiro, S. (2012). The retention of South African female chartered accountants in public practice. Unpublished master's dissertation, University of Johannesburg, South Africa

FIGURE 1: Theoretical model on the impact of job demands and resources on turnover intentions of women chartered accountants.
Of this sample, 851 responses were returned, resulting in a $12 \%$ response rate. Survey fatigue as well as work pressure may have accounted for the response rate. Frequency statistics revealed that, of the 851 responses, 281 women or $33 \%$ were qualified CAs who held management or partnership positions, and 566 respondents indicated that they were trainee CAs in the process of meeting the SAICA qualification requirements with the vast majority having completed a Certificate of Theory in Accounting along with their Bachelor's degrees. With regard to race, as stated according to the South African government's classification system, 15\% were Asian or Indian, 21\% black African, 6\% mixed race (individuals of mixed race), and $56 \%$ white. As would be expected, qualified CAs were older, with longer tenure in public practice firms, and had more dependants, compared to trainee CAs.

\section{Measures}

Building on Demerouti et al.'s (2001b) conceptualisation of the JD-R model, Jackson and Rothmann (2005) developed the Job Demands-Resources Scale (JDRS). The scale consists of 48 items: operationalising workload, pace, emotional load, variety in work, opportunities to learn, communicating, remuneration, and relationships with colleagues and supervisors, as well as career possibilities. Responses are rated on a four-point Likert-type scale ranging from 1 (Never) to 4 (Always). Rothmann, Mostert and Strydom (2006) found support for the following five factors of the JDRS in the South African context: Growth opportunities (7 items), Organisational support (18 items), Advancement (6 items), Job overload (8 items), and Job insecurity (3 items). Rothmann et al. (2006) found the following reliabilities for the factors Growth opportunities $-\alpha=0.86$, Organisational support $-\alpha=0.92$, Advancement $-\alpha=0.83$, Job overload $-\alpha=0.76$, and job insecurity $-\alpha=0.89$.

De Braine and Roodt (2011) argued for a more comprehensive taxonomy, and supplemented the model of Rothmann et al. (2006) with the inclusion of perceived external Prestige (5 items), Team climate (6 items), and Work-family conflict (5 items). Riordan, Gatewood and Bill (1997) conceptualised a five-item scale of perceived prestige, measured with a seven-point Likert-type scale ranging from 1 (Not good at all) to 7 (Extremely good). The Cronbach's alpha coefficient of the scale $(\alpha=0.90)$ was indicative of a reliable measure. An adapted version of Klivimaki and Elovaino's (1999) six-item scale was utilised to measure team climate. Responses were rated on a seven-point Likert-type scale ranging from 1 (Not very well at all) to 7 (Very well). The internal consistency reported for this scale was 0.89 . Work-family conflict was measured with a work-family conflict scale that was adapted from that of Netemeyer, Boles, and McMurrian (1996). Responses were rated on a seven-point Likert-type scale ranging from 1 (Never) to 7 (Always). The internal consistency reported for the Netemeyer, Boles and McMurrian (1996) scale was 0.96. Roodt's (2004) Turnover Intention Scale was used to measure turnover intentions. Responses on the 
six-item scale are quantified by means of a seven-point Likert scale. The scale has been found to demonstrate acceptable internal consistency reliability ( $\alpha=0.81, \mathrm{M}=25.21, \mathrm{SD}=8.10)$.

\section{Statistical analysis}

Structural Equation Modelling (SEM) with MPLUS (Version 6, Muthén \& Muthén, 2010) was used. The means and covariance structures were analysed with the Robust Maximum Likelihood estimator, because of the nonnormality of the manifest variables. Confirmatory factor analyses identified some problematic items, which were removed from the scales to reduce the amount of error variance. The fit of the models was assessed with the SatorraBentler chi-square $\left(\chi^{2}\right)$, the root mean square error of approximation (RMSEA), the comparative fit index (CFI), and the Tucker-Lewis Index (TLI).

In the second phase of analysis, the moderating (i.e. buffer) effect of job resources (growth opportunities, social support, advancement, prestige, and team climate) on the relationship between job demands (work-family conflict, job overload, and job insecurity) and turnover intentions was investigated with moderated regression analysis (Cohen, Cohen, West \& Aiken, 2003). In this study we used a combination of SEM (to test direct relationships) and regression analysis (to test interaction effects). A combination of the two methods strengthens the research design.

The moderating potential of each of the five job resources on the relationship between job demands and turnover intentions was assessed across three levels of job resources (work-family conflict, job overload, and job insecurity) by means of a hierarchical multiple regression approach (Aguinis, Beaty, Boik \& Pierce, 2005; Cohen et al., 2003). Substantive propositions were empirically corroborated when the direction, magnitude, and statistical significance of path coefficients were congruent with a priori theorising.

\section{Results}

In the first part of the results section, the direct effects of job demands and job resources on turnover intentions were investigated using a covariance modelling approach. The second part of the section investigates the moderating role of job resources in buffering the adverse impact of job demands on turnover intentions.

\section{Descriptive statistics}

The correlations and internal consistency between the variables included in the study are summarised in Table 1. As expected, moderately strong positive correlations were reported between the job demands indicators and turnover intentions (except job insecurity), whereas negative correlations were found between job resources and turnover intentions. All the internal consistencies of the scales were acceptable, because all reported Cronbach alphas were well above 0.70 (Nunnally, 1978).

\section{Assessment and measurement models}

In total, nine Confirmatory Factor Analysis (CFA) models were specified for each individual scale included in the structural model. The CFA models were analysed to establish the measurement quality of the scales prior to incorporating them into the structural model. As was the case with the Exporatory Factor Analysis (EFA) and item analyses, item DQ2R was removed because of low factor loading $(\lambda=0.15)$. The overall fit of the refined exogenous measurement model was satisfactory (S-B $\chi^{2}=1955.55, d f=602, p<0.05$; RMSEA = 0.060, $p<0.05$, CFI: 0.882; TLI: 0.870; SRMR: 0.069) and deemed appropriate for constructing the proposed structural model. Although the CFI and TLI values did not conform to the strict guidelines advocated by $\mathrm{Hu}$ and Bentler (1999), the deviation was marginal. Thus, considering the fit indices and model parameters collectively, the fit of the exogenous measurement model to the data can be described as adequate.

Because only turnover intentions constituted the endogenous measurement model, interpreting the adequacy of the model was considerably simpler. The overall fit of the refined endogenous measurement model was satisfactory (S-B $\chi^{2}=$ 46.225, $d f=9, p<0.05$; RMSEA $=0.082, p<0.05$, CFI: 0.960; TLI: 0.943; SRMR: 0.035).

\section{Assessment of the structural model Model fit}

Residuals provide important information regarding overall model fit (Jöreskog \& Sörbom, 1996; Kelloway, 1998). The frequency distributions of the standardised residuals followed a marginally negatively skewed distribution, which approximated a normal distribution. Goodness-of-fit indices pertaining to the balanced model of work wellness are reported in Table 2 .

In general, the results reported in Table 2 suggest that the proposed structural model mapping various job demands and job resources on turnover intentions provides a reasonable account of the empirical data. Most of the fit indices are within the normative ranges, with the exception of the CFI and TIL, which are marginally lower than the normative cut-off value of 0.90 (Hair, Black, Babin, Anderson \& Tatham, 2006). Kline (2005) argues that model fit should also be evaluated on a more molecular level by looking at specific model parameters. The next section will investigate the empirical merits of the proposed model by investigating the proposed relationships between variables constituting the model.

\section{Model parameters}

Structural regression parameters pertaining to the proposed structural model are presented in Table 3. In line with initial theorising, turnover intentions were negatively related to growth opportunities $(\beta=-0.451 ; p<0.001)$ and team climate ( $\beta=-0.276 ; p<0.001)$. Contrary to initial theorising, social support, advancement, and prestige did not seem to be significant predictors of turnover intentions. 
TABLE 1: Correlations between the study variables and internal consistencies (Cronbach's coefficient alphas on the diagonal).

\begin{tabular}{|c|c|c|c|c|c|c|c|c|c|}
\hline Variable & 1 & 2 & 3 & 4 & 5 & 6 & 7 & 8 & 9 \\
\hline 1. Job overload & -0.85 & - & - & - & - & - & - & - & - \\
\hline 2. Job insecurity & -0.069 & -0.89 & - & - & - & - & - & - & - \\
\hline 3. Work-family conflict & $0.573 * *$ & $-0.163 * *$ & -0.97 & - & - & - & - & - & - \\
\hline 4. Growth opportunities & $0.185^{* *}$ & $0.411 * *$ & -0.01 & -0.85 & - & - & - & - & - \\
\hline 5. Social support & $-0.076 *$ & $0.338^{* *}$ & $-0.253 * *$ & $0.472 * *$ & -0.83 & - & - & - & - \\
\hline 6. Advancement & -0.043 & $0.367 * *$ & $-0.114 * *$ & $0.443 * *$ & $0.284 * *$ & -0.88 & - & - & - \\
\hline 7. Perceived external prestige & -0.014 & $0.290 * *$ & -0.029 & $0.402 * *$ & $0.399 * *$ & $0.359 * *$ & -0.91 & - & - \\
\hline 8. Team climate & 0.004 & $0.419 * *$ & $-0.136 * *$ & $0.557 * *$ & $0.612 * *$ & $0.477^{* *}$ & $0.550 * *$ & -0.91 & - \\
\hline 9. Turnover intentions & $0.214 * *$ & $-0.480 * *$ & $0.355^{* *}$ & $-0.574 * *$ & $-0.503 * *$ & $-0.456 * *$ & $-0.406 * *$ & $-0.603 * *$ & -0.85 \\
\hline
\end{tabular}

$*, p<0.05 ; * *, p<0.001$

TABLE 2: Goodness-of-fit statistics for the structural model.

\begin{tabular}{|c|c|c|}
\hline Fit indices & Criteria & Result \\
\hline \multirow[t]{8}{*}{ Absolute fit indices } & Chi-square test of model fit & 2512.479 \\
\hline & Degrees of freedom & 824 \\
\hline & $p$ & 0.000 \\
\hline & $\begin{array}{l}\text { Scaling correction factor for } \\
\text { robust } \mathrm{ML}\end{array}$ & 1.169 \\
\hline & $\begin{array}{l}\text { RMSEA (root mean square error } \\
\text { of approximation) }\end{array}$ & 0.057 \\
\hline & $p$-value RMSEA $(\leq 0.05)$ & 0.000 \\
\hline & $90 \% \mathrm{Cl}$ & $0.055-0.060$ \\
\hline & $\begin{array}{l}\text { Standardised root mean squared } \\
\text { residual (RMR) }\end{array}$ & 0.064 \\
\hline \multirow[t]{2}{*}{ Incremental Fit indices } & Comparative fit index (CFI) & 0.875 \\
\hline & Tucker-Lewis Fit Index (TLI) & 0.863 \\
\hline
\end{tabular}

TABLE 3: Direct effects of job demand and job resources on turnover intentions $(n=851)$.

\begin{tabular}{lllll}
\hline Characteristic & Predictor & \multicolumn{3}{c}{ Turnover intentions } \\
\cline { 3 - 5 } & & UPC & SE & SPC \\
\hline Job resources & Growth opportunities & -0.632 & 0.092 & $-0.451^{* * *}$ \\
& Social support & 0.032 & 0.086 & 0.022 \\
& Advancement & -0.047 & 0.048 & -0.046 \\
& Prestige & 0 & 0.062 & 0 \\
& Team climate & -0.432 & 0.089 & $-0.276 * * *$ \\
Job demands & Job overload & 0.241 & 0.064 & $0.200^{* * *}$ \\
& Work-family conflict & 0.174 & 0.052 & $0.158^{* * *}$ \\
& Job insecurity & -0.054 & 0.037 & -0.06 \\
\hline
\end{tabular}

UPC, un-standardised path coefficient; SE, standard error; SPC, standardised path coefficient. $* * *, p<0.001$.

With regard to job demands, statistically significant positive relationships were found between Turnover intentions and Job overload ( $\beta=0.200 ; p<0.001)$, and Turnover intentions and Work-family conflict $(\beta=-0.158 ; p<0.001)$. These findings support the initial theorising, which predicted that job demands are likely to advance turnover intentions. No statistical support was found for the proposed relationship between Turnover intentions and Job insecurity.

Examination of the goodness-of-fit indices, residuals, and model parameters indicated that the proposed theoretical model reproduced the covariances in the observed covariance with acceptable, albeit not satisfactory, levels of precision. In total, $50 \%$ of the a priori propositions were confirmed in the SEM analysis. This may be regarded as strong support that job demands promote turnover intentions, whereas job resources counter turnover intentions. However, of further interest would be to examine if job resources buffer the adverse impact of job demands on turnover intentions.
Thus, the secondary research objective of the current study will be investigated in more detail in the subsequent section.

\section{Moderated regression analysis}

A hierarchical multiple regression approach was utilised, where the main effects constituting the interaction effect were entered in Step 1, and the main effects plus interaction effect were entered in Step 2. Results of the moderated regression analysis are presented in Table 4.

The pattern of significant results in Table 4 provides further support for the a priori propositions insofar as Job resources consistently report a negative relationship with Turnover intentions, whereas Job demands reported a positive relationship with Turnover intentions. However, contrary to expectations, a negative relationship was found between Job insecurity and Turnover intentions. Similar results were found in the SEM analysis, although the relationship was not statistically significant.

Turning to the interaction effects, not one of the five job resources significantly moderated the relationship between Overload and Turnover intentions. However, statistical support was found for the moderating (i.e. buffering) role of all Job resources, except Advancement, on the relationship between Work-family conflict and Turnover intentions. Similar results were found with regard to the buffering role of Job resources on the relationship between Job insecurity and Turnover intentions. In the latter case, only Growth opportunities failed to explain the additional variance in Turnover intentions, when the constituent main effects were taken into consideration. Effect sizes for the statistically significant interaction effects were quite small, ranging between $0.4 \%$ and $1.6 \%$. Taken together, statistical support was found for 8 of the $15(54 \%)$ interaction terms, providing empirical support for the moderating potential of job resources in the stress-strain sequence for South African women CAs in public practice firms.

\section{Discussion}

The present study shows that job demands promote turnover intentions, whereas job resources combat turnover intentions of women working in the accountancy profession in South African public practice firms. In general, the pattern of results 
TABLE 4: Results of the moderated regression analysis: Interactions between job resources and job demands in predicting turnover intentions $(n=851)$.

\begin{tabular}{|c|c|c|c|c|c|c|c|c|c|}
\hline \multirow[t]{3}{*}{ Characteristic } & \multirow[t]{3}{*}{ Step } & \multirow[t]{3}{*}{ Predictor } & \multicolumn{7}{|c|}{ Turnover intentions } \\
\hline & & & \multicolumn{4}{|c|}{ Model parameters } & \multicolumn{3}{|c|}{ Effect sizes } \\
\hline & & & $B$ & SE & $\beta$ & $p$ & $R$ & $R^{2}$ & $\Delta R^{2}$ \\
\hline \multirow[t]{15}{*}{ Job overload } & 1. & Overload & 0.475 & 0.041 & 0.347 & 0.001 & 0.664 & 0.441 & - \\
\hline & & Growth opportunities & -0.670 & 0.031 & -0.633 & 0.001 & - & - & - \\
\hline & 2. & Overload $\times$ growth opportunities & 0.029 & 0.028 & 0.031 & 0.287 & 0.665 & 0.442 & 0.001 \\
\hline & 1. & Overload & 0.256 & 0.044 & 0.188 & 0.001 & 0.536 & 0.287 & - \\
\hline & & Social support & -0.582 & 0.039 & -0.489 & 0.001 & - & - & - \\
\hline & 2. & Overload $\times$ social support & 0.039 & 0.035 & 0.036 & 0.266 & 0.536 & 0.289 & 0.001 \\
\hline & 1. & Overload & 0.289 & 0.046 & 0.212 & 0.001 & 0.500 & 0.250 & - \\
\hline & & Advancement & -0.419 & 0.031 & -0.449 & 0.001 & - & - & - \\
\hline & 2. & Overload $\times$ advancement & 0.055 & 0.032 & 0.058 & 0.083 & 0.503 & 0.253 & 0.003 \\
\hline & 1. & Overload & 0.311 & 0.047 & 0.228 & 0.001 & 0.465 & 0.216 & - \\
\hline & & Prestige & -0.491 & 0.041 & -0.402 & 0.001 & - & - & - \\
\hline & 2. & Overload $\times$ prestige & 0.037 & 0.039 & 0.033 & 0.335 & 0.466 & 0.217 & 0.001 \\
\hline & 1. & Overload & 0.334 & 0.040 & 0.245 & 0.001 & 0.648 & 0.421 & - \\
\hline & & Team climate & -0.640 & 0.031 & -0.603 & 0.001 & - & - & - \\
\hline & 2. & Overload $\times$ team climate & 0.030 & 0.029 & 0.030 & 0.308 & 0.649 & 0.421 & 0.001 \\
\hline \multirow{15}{*}{$\begin{array}{l}\text { Work-family } \\
\text { conflict }\end{array}$} & 1. & Work-family conflict & 0.305 & 0.024 & 0.354 & 0.001 & 0.670 & 0.449 & - \\
\hline & & Growth opportunities & -0.600 & 0.030 & -0.567 & 0.001 & - & - & - \\
\hline & 2. & $\begin{array}{l}\text { Work-family conflict } \times \text { growth } \\
\text { opportunities }\end{array}$ & 0.052 & 0.018 & 0.084 & 0.003 & 0.675 & 0.456 & 0.007 \\
\hline & 1. & Work-family conflict & 0.210 & 0.028 & 0.244 & 0.001 & 0.557 & 0.311 & - \\
\hline & & Social support & -0.530 & 0.039 & -0.446 & 0.001 & - & - & - \\
\hline & 2. & $\begin{array}{l}\text { Work-family conflict } \times \text { social } \\
\text { support }\end{array}$ & 0.044 & 0.022 & 0.064 & 0.045 & 0.561 & 0.315 & 0.004 \\
\hline & 1. & Work-family conflict & 0.263 & 0.028 & 0.305 & 0.001 & 0.544 & 0.295 & - \\
\hline & & Advancement & -0.384 & 0.030 & -0.410 & 0.001 & - & - & - \\
\hline & 2. & $\begin{array}{l}\text { Work-family conflict } \times \\
\text { advancement }\end{array}$ & 0.044 & 0.018 & 0.076 & 0.076 & 0.549 & 0.301 & 0.006 \\
\hline & 1. & Work-family conflict & 0.299 & 0.028 & 0.348 & 0.001 & 0.530 & 0.281 & - \\
\hline & & Prestige & -0.486 & 0.039 & -0.398 & 0.001 & - & - & - \\
\hline & 2. & Work-family conflict $\times$ prestige & 0.092 & 0.023 & 0.128 & 0.001 & 0.546 & 0.298 & 0.016 \\
\hline & 1. & Work-family conflict & 0.241 & 0.025 & 0.280 & 0.001 & 0.661 & 0.437 & - \\
\hline & & Team climate & -0.596 & 0.031 & -0.562 & 0.001 & - & - & - \\
\hline & 2. & $\begin{array}{l}\text { Work-family conflict } \times \text { team } \\
\text { climate }\end{array}$ & 0.044 & 0.017 & 0.072 & 0.012 & 0.665 & 0.443 & 0.005 \\
\hline \multirow[t]{15}{*}{ Job insecurity } & 1. & Job insecurity & -0.236 & 0.025 & -0.311 & 0.001 & 0.633 & 0.400 & - \\
\hline & & Growth opportunities & -0.475 & 0.034 & -0.449 & 0.001 & - & - & - \\
\hline & 2. & $\begin{array}{l}\text { Job insecurity } \times \text { growth } \\
\text { opportunities }\end{array}$ & -0.034 & 0.017 & -0.059 & 0.054 & 0.635 & 0.404 & 0.003 \\
\hline & 1. & Job insecurity & -0.275 & 0.025 & -0.362 & 0.001 & 0.602 & 0.363 & - \\
\hline & & Social support & -0.468 & 0.039 & -0.394 & 0.001 & - & - & - \\
\hline & 2. & Job insecurity $\times$ social support & -0.044 & 0.018 & -0.074 & 0.018 & 0.607 & 0.368 & 0.005 \\
\hline & 1. & Job insecurity & -0.295 & 0.026 & -0.388 & 0.001 & 0.569 & 0.323 & - \\
\hline & & Advancement & -0.299 & 0.031 & -0.320 & 0.001 & - & - & - \\
\hline & 2. & Job insecurity $\times$ advancement & -0.040 & 0.016 & -0.079 & 0.016 & 0.574 & 0.329 & 0.006 \\
\hline & 1. & Job insecurity & -0.305 & 0.025 & -0.403 & 0.001 & 0.555 & 0.308 & - \\
\hline & & Prestige & -0.379 & 0.042 & -0.311 & 0.001 & - & - & - \\
\hline & 2. & Job insecurity $\times$ prestige & -0.040 & 0.019 & -0.072 & 0.032 & 0.560 & 0.313 & 0.005 \\
\hline & 1. & Job insecurity & -0.224 & 0.025 & -0.295 & 0.001 & 0.650 & 0.423 & - \\
\hline & & Team climate & -0.520 & 0.034 & -0.491 & 0.001 & - & - & - \\
\hline & 2. & Job insecurity $\times$ team climate & -0.054 & 0.016 & -0.100 & 0.001 & 0.658 & 0.432 & 0.009 \\
\hline
\end{tabular}

$B$, un-standardised regression coefficient; SE, standard error of $B ; \beta$, the standardised regression coefficient; $p$, probability value; $R^{2}$, coefficient of determination; $\Delta R^{2}$, change in the coefficient of determination.

between the five job resources, three job demands, and turnover intentions provided support for the aforementioned thesis. This finding is important for public practice managers as it provides a theoretical framework with which they can view the jobs of women accountants. Utilising the JD-R model, managers may be able to manipulate job characteristics, instead of person-specific characteristics, to reduce health impairment and to motivate women employees, thereby reducing turnover intentions. There was, however, a negative direct effect between job insecurity and turnover intentions in the regression analysis. Based on national employment expectations data, Dickerson and Green (2012) indicate that, for an individual, the fear of losing one's job (job insecurity) is usually overestimated and the reality of replacing a job underestimated. Vast research support is found for the positive relationship between job insecurity 
and voluntary turnover, especially for highly qualified workers with rare skills (Stedham \& Mitchell, 1996; Sverke, Hellgren \& Naswall, 2002; Vinokur-Kaplan, Jayaratne \& Chess, 1994). 'However, other researchers (e.g. Borg \& Elizur, 1992; Repenning, 2000; Van Vuuren, Klandermans, Jacobson \& Hartley, 1991) have argued that job insecurity might have the opposite effect on performance and withdrawal behaviour' (Konig \& Staufenbiel, 2010, p. 101). The fear of losing one's job may motivate vulnerable employees to actively cope with the threat by increasing visibility and work output. In a cross-cultural study in Israel and the Netherlands, Van Vuuren et al. (1991) asked more than 500 employees about perceived safeguards against involuntary job loss. The vast majority of participants in both countries believed that high personal output protected them best against involuntary turnover. These findings are congruent with stress theory, where job insecurity may be viewed as a challenge stressor, as opposed to a hindrance stressor, that triggers active problem-solving as a coping strategy (Cavanaugh, Boswell, Roehling \& Boudreau, 2000). In the case of South African women CAs, who have a skill-set that is in high demand and who are presently underrepresented in the workplace, the finding that turnover intentions do not increase when job insecurity increases could be explained by the challenge stressor theory. In our study $56 \%$ of the survey respondents were white women who might feel insecure about finding alternative job opportunities because of legislation that aims to reconfigure racial representation in the workplace (South Africa, 1998). Furthermore, women and other marginalised groups would react to stereotype threat, where women CAs are in the minority in public practice firms, the stereotype that being an accountant is 'not appropriate female behaviour' (AndersonGough, Grey \& Robson, 2005, p. 471) is constantly invoked (Hoyt, Johnson, Murphy \& Skinnell, 2010). Once the stereotype threat is invoked, women will experience job insecurity and start exhibiting additional effort when measured against men to ensure continued employment and relevance in the team or firm.

In addition, the study found support for the buffering proposition of job resources in the stress-turnover perceptions sequence. The moderated regression analysis suggested that 8 of the 15 interaction effects were statistically significant. Thus, different combinations of job demands and job resources explained significant amounts of variance in turnover intentions. These findings are consistent with previous research on the buffer proposition of the JD-R model, indicating that several job resources can mitigate the adverse impact of job demands on health and turnover intentions (Bakker et al., 2003a). The results suggest that the model is equally effective in predicting turnover intentions amongst the sample of women accountants employed in South African public practice firms.

Results from the study support Bakker and Demerouti (2007) theory that not all job resources are equally effective in combating the adverse consequences of job demands. In the current study we see that none of the five job resources were effective in buffering the adverse impact of job overload on turnover intentions. These results may suggest that the impact of job overload on turnover intentions is so pervasive and strenuous amongst women accountants working in public practice in South Africa that no single job resource measured (i.e. growth opportunities, social support, advancement, perceived external prestige, and team climate) was able to buffer its impact. High work volumes and long hours spent working and travelling to out-of-town assignments are part and parcel of a South African accountant's job (Sadler, 1989) which may contribute negatively to the retention of women accountants, given that women carry the bulk of care and household tasks in addition to work demands. According to stress theory, job overload can thus be regarded as a hindrance stressor which impairs performance and promotes turnover intentions of women CAs in public practice firms.

The impact of work-family conflict is buffered by growth opportunities, social support, perceived external organisational prestige, and a positive team climate. Financial advancement which includes career possibilities, did not buffer the impact of work-family conflict on turnover intentions. This finding suggests that the adage of paying people inflated salaries would not necessarily ensure that women CAs are retained by public practice firms. CAs already earn high salaries and therefore women would not necessarily seek additional financial reward. Instead the job resources that do buffer work-family conflict are all intangible. There has recently been a growing trend within organisations to focus on the importance of the so-called 'human factors', and many women CAs working in public practice firms may benefit more from organisational cultures that are accommodating of difference (Bakker \& Derks, 2010; Snyder \& Lopez, 2002; Strümpfer, 1990, 2003) instead of increased financial advancement. South African women CAs are therefore indicating that public practice firms should exert careful planning when considering their employee management practices rather than merely just 'throwing money at the problem'. In addition, research suggests that the incentives for organisations to promote women may be reduced if they do not have access to leadership roles early on in their careers (Bell, 2009). Promoting women early on in their careers may also aid in buffering work-family conflict as younger professional women often may not experience intense work-family conflict and could be in more senior roles by the time that the conflict starts setting in for them.

Arguably the most innovative theoretical contribution made by this study is the distinction between challenging and hindrance stressors and the moderating impact of job resources on them. The negative relationships between turnover intentions and job insecurity suggest that women accountants in public practice firms are actively engaged by their perceptions of job insecurity (i.e. a challenge stressor). However, higher levels of job resources (i.e. social support, advancement, prestige, and team climate) buffer this 
relationship. Stated differently, women accountants in public practice firms who experience high levels of social support, advancement, prestige, and team climate experience lower levels of turnover intentions than those with lower levels of these job resources, especially when high levels of job insecurity are present. The findings also imply that providing women CAs with more job variety and opportunities to learn (growth opportunities) does not reduce their perceived job insecurity. This finding is alarming when considering that Rothmann and Rothmann (2010) found that growth opportunities have the strongest effect on employee engagement, but may be explained by Hall and Smith's (2009) finding that mentoring for career development leads to an increase in turnover intentions for accountants. However, the positive image and reputation of a public practice firm as well as a positive team climate, social support from managers and colleagues, and satisfactory remuneration, could create a perception that public practice firms are stable supportive communities where jobs are relatively secure.

\section{Limitations}

Statistically significant interaction effects remain quite elusive in the social sciences, despite the widespread application of interactionist theories (Klein \& Muthén, 2007; Marsh, Wen \& Hau, 2004; Moulder \& Algina, 2002). It is therefore remarkable that empirical support has been found for more than $50 \%$ of the proposed directional paths. However, the effect size was very modest and one should be careful about generalising the result to the broader population of women accountants in South African public practice firms.

Another drawback is the cross-sectional nature of the study, whereby temporal stability is ambiguous rather than sequential (Kerlinger \& Lee, 2000). Making causal inferences regarding the relationships between job demands, job resources, and turnover intentions would be imprudent, yet there is congruence between a priori theorising and empirical results which are clearly supportive of the JD-R model (Bakker et al., 2003a) which is also supported by the conservation of resources theory (Hobfoll, 1989, 2002). This strengthens the degree of confidence in the linear causal relationships proposed in the structural model.

Alternative job demands and job resources might also be uncovered if the study was preceded by a qualitative investigation of the job characteristics of accountants instead of relying solely on available literature. The counter-intuitive finding of a negative direct effect between job insecurity and turnover intentions should be tested in samples that include men. Presently it remains unclear whether job insecurity is a challenge stressor specifically for women accountants.

Finally, the use of self-report questionnaires reflects participants' perceptions, which may or may not reflect objective reality. As a result, future research should try to replicate the findings in the study with a combination of research approaches (e.g. experimental) and measures (e.g. objective strain measurement, diary approach).

\section{Conclusion}

The global accountancy profession has a clear interest in stopping the attrition of women accountants from public practice firms. The findings in the study indicate those job resources and job demands that in combination may combat turnover intentions, thereby supporting the finding of Minnotte (2016) that the interaction of these factors matter for women. At the most basic level, the findings seem to suggest that organisations reduce hindrance stressors, like overload. The converse, though not specifically probed in this study, remains equally important: provide employees with enough stretch goals in the form of challenging stressors to keep them engaged and motivated. Admittedly, differentiating between the two categories of stressors, namely, challenge, and hindrance stressors, and their optimal level of arousal needed to promote work engagement and high performance, remains as much an art as a science.

\section{Acknowledgements}

An earlier version of this paper was presented at the Equality, Diversity, and Inclusion conference in Greece. The Women in the Workplace Research Reports describe different aspects of the same study.

\section{Competing interests}

The authors declare that they have no financial or personal relationships which may have inappropriately influenced them in writing this article.

\section{Authors' contributions}

S.R. was the project leader and Master's degree student. A.B. was the co-supervisor who made substantial theoretical and conceptual contributions. J.B. was the methodologist who did the statistical analyses and reporting.

\section{References}

Aguinis, H., Beaty, J.C., Boik, R.J., \& Pierce, C.A. (2005). Effect size and power in assessing moderating effects of categorical variables using multiple regression: A 30-year review. Journal of Applied Psychology, 90(1), 94-106.

Anderson-Gough, F., Grey, C., \& Robson, K. (2005). "Helping them to forget": The organizational embedding of gender relations in public audit firms. Accounting, Organizations and Society, 30(5), 469-490.

Armstrong, P. (2000). Accounting for insecurity. Critical Perspectives on Accounting, 11(4), 383-406.

Bakker, A., Demerouti, E., \& Schaufeli, W. (2003a). Dual processes at work in a call centre: An application of the job demands-resources model. European Journal of Work and Organizational Psychology, 12(4), 393-417.

Bakker, A., Van Veldhoven, M., \& Xanthopoulou, D. (2010). Beyond the demandcontrol model. Journal of Personnel Psychology, 9(1), 3-16.

Bakker, A.B., \& Demerouti, E. (2007). The job demands-resources model: State of the art. Journal of Managerial Psychology, 22(3), 309-328.

Bakker, A.B., Demerouti, E., Taris, T.W., Schaufeli, W.B., \& Schreurs, P.J. (2003b). A multigroup analysis of the job demands-resources model in four home care organizations. International journal of stress management, 10(1), 16-38.

Bakker, A.B., Demerouti, E., \& Verbeke, W. (2004). Using the job demands-resources model to predict burnout and performance. Human Resource Management, 43(1), 83-104.

Bakker, A.B., \& Derks, D. (2010). Positive occupational health psychology. Occupational health psychology: A key text. Oxford: Wiley-Blackwell, pp. 194-224.

Barker, P.C., \& Monks, K. (1998). Irish women accountants and career progression: A research note. Accounting, Organizations and Society, 23(8), 813-823.

Bell, S. (2009). Women in science in Australia: Maximising productivity, diversity and innovation. Federation of Australian Scientific and Technological Societies, pp. 1-96. 
Bester, F., Roodt, G., \& Bosch, A. (2012). Work identity, work engagement and turnover, Pan Pacific Conference. Haikou, Hainan Island: China Pan Pacific Business turnover, Pan

Borg, I., \& Elizur, D. (1992). Job insecurity: Correlates, moderators and measurement. International Journal of Manpower, 13(2), 13-26.

Bosch, A., Ribeiro, S., \& Becker, J. (2012). Women in the Workplace Research Report: Keeping South Africa's female chartered accountants in public-practice. Women in the Workplace Research Programme, Department of Industrial Psychology and People Management, Auckland Park, South Africa: University of Johannesburg.

Cabrera, E.F. (2007). Opting out and opting in: Understanding the complexities of women's career transitions. Career Development International, 12(3), 218-237.

Carmeli, A., \& Gefen, D. (2005). The relationship between work commitment models and employee withdrawal intentions. Journal of Managerial Psychology, 20(2), 63-86.

Cavanaugh, M.A., Boswell, W.R., Roehling, M.V., \& Boudreau, J.W. (2000). An empirical examination of self-reported work stress among US managers. Journal of Applied Psychology, 85(1), 65-74.

Cohen, J., Cohen, P., West, S.G., \& Aiken, L.S. (2003). Applied multiple correlation/ regression analysis for the social sciences. Hillsdale, NJ: Erlbaum.

Collins, K.M. (1993). Stress and departures from the public accounting profession: A study of gender differences. American Accounting Association, Accounting Horizons, 7(1), 29-38.

Crosley, G. (2006). Where are all the women rainmakers in accounting? Accounting Today, 20(12), 9 .

Dambrin, C., \& Lambert, C. (2008). Mothering or auditing? The case of two big four in France. Accounting, Auditing and Accountability Journal, 21(4), 474-506.

De Braine, R., \& Roodt, G. (2011). The job demands-resources model as predictor of work identity and work engagement: A comparative analysis. SA Journal of Industrial Psychology, 37(2), 52-62.

Deci, E.L., \& Ryan, R.M. (1985). Intrinsic motivation and self-determination in human behaviour. New York: Plenum.

Demerouti, E., \& Bakker, A.B. (2011). The Job Demands-Resources model: Challenges for future research. South African Journal of Industrial Psychology, 37(2), 1-9.

Demerouti, E., Bakker, A.B., de Jonge, J., Janssen, P.P.M., \& Schaufeli, W.B. (2001a). Burnout and engagement at work as a function of demands and control Scandinavian Journal of Work, Environment and Health, 27(4), 279-286.

Demerouti, E., Bakker, A.B., Nachreiner, F., \& Schaufeli, W.B. (2001b). The job demands resources model of burnout. Journal of Applied Psychology, 86(3), 499-512.

Dickerson, A., \& Green, F. (2012). Fears and realisations of employment insecurity. Labour Economics, 19(2), 198-210.

Gammie, E., Gammie, B., Matson, M., \& Duncan, F. (2007). Women of ICAS reaching the top: The demise of the glass ceiling. Edinburgh: The Institute of Chartered the top: The demise of the
Accountants of Scotland.

Gold, L. (2008a). It's not just for women anymore! Accounting Today, 22(13), 1-38.

Gold, L. (2008b). Challenges remain for women of color in accounting. Accounting Today, 4(17), 8-30.

Hair, J.F., Black, W.C., Babin, B.J., Anderson, R.E., \& Tatham, R.L. (2006). Multivariate data analysis (6th edn.). Upper Saddle River, NJ: Pearson Education Inc.

Hakanen, J.J., \& Roodt, G. (2010). Work engagement Chapter 7. In A.B. Bakker \& M.P. Leiter (Eds.), A handbook of essential theory and research (pp. 85-101). Sussex: Psychology Press.

Hall, M., \& Smith, D. (2009). Mentoring and turnover intentions in public accounting firms: A research note. Accounting, Organizations and Society, 34(6-7), 695-704.

Haynes, K. (2008). (Re)figuring accounting and maternal bodies: The gendered embodiment of accounting professionals. Accounting, Organizations and Society, 33(4-5), 328-348.

Hilton, M.F. (2008). The prevalence of psychological distress in employees and associated occupational risk factors. Journal of Occupational and Environmental Medicine, 50(7), 746-757.

Hobfoll, S.E. (1989). Conservation of resources. American Psychologist, 44(3), 513-524.

Hobfoll, S.E. (2002). Social and psychological resources and adaptation. Review of General Psychology, 6(4), 307-324.

Hoyt, C.L., Johnson, S.K., Murphy, S.E., \& Skinnell, K.H. (2010). The impact of blatant stereotype activation and group sex-composition on female leaders. The Leadership Quarterly, 21(5), 716-732.

Hu, L.T., \& Bentler, P.M. (1999). Cut-off criteria for fit indexes in covariance structure analysis: Conventional criteria versus new alternatives. Structural Equation Modeling: A Multidisciplinary Journal, 6(1), 1-55.

Jackson, L.T.B., \& Rothmann, S. (2005). An adapted model of burnout for educators in South Africa. South African Journal of Education, 25(2), 100-108.

Johnson, E.N., Lowe, D., \& Reckers, P.M.J. (2008). Alternative work arrangements and perceived career success: Current evidence from the big four firms in the US. Accounting, Organizations and Society, 33(1), 48-72.

Jöreskog, K.G., \& Sörbom, D. (1996). PRELIS 2 User's reference guide: A program for multivariate data screening and data summarization, LISREL, Lincolnwood, Illinois, United States of America: Scientific Software International.

Kain, J., \& Jex, S. (2010). Karasek's (1979) Job demand-control model: A summary of current issues and recommendations for future research. In P.L. Perrewé \& D.C Ganster (Eds.), New developments in theoretical and conceptual approaches to job stress (Vol. 8, pp. 237-268). Bingley, United Kingdom.
Kamla, R. (2012). Syrian women accountants' attitudes and experiences at work in the context of globalization. Accounting, Organizations and Society, 37(3), 188-205.

Kelloway, E.K. (1998). Using LISREL for structural equation modeling: A researcher's guide. Thousand Oaks: Sage Publications.

Kerlinger, F.N., \& Lee, H.B. (2000). Survey research: Foundations of behaviora research. Fort Worth, TX: Harcourt College Publishers, pp. 599-619.

Klein, A.G., \& Muthén, B.O. (2007). Quasi-maximum likelihood estimation of structural equation models with multiple interaction and quadratic effects. Multivariate Behavioral Research, 42(4), 647-673.

Kline, R.B. (2005). Principles and practice of structural equation modelling. New York: Guilford.

Klivimaki, M., \& Elovainio, M. (1999). A short version of the team climate inventory, development and psychometric properties. Journal of Occupational and Organisational Psychology, 72(2), 241-246.

Konig, C.J., \& Staufenbiel, T. (2010). A model for the effects of job insecurity on performance, turnover intention, and absenteeism. Journal of Occupational and Organizational Psychology, 83(1), 101-107.

Kornberger, M., Carter, C., \& Ross-Smith, A. (2010). Changing gender domination in a Big Four accounting firm: Flexibility, performance and client service in practice. Accounting, Organizations and Society, 35(8), 775-791.

Kornberger, M., Justesen, L., \& Mouritsen, J. (2011). "When you make manager, we put a big mountain in front of you": An ethnography of managers in a big 4 accounting firm. Accounting, Organizations and Society, 36(8), 514-533.

Lewis, S., \& Humbert, L. (2010). Discourse or reality?: "Work-life balance," flexible working policies and the gendered organization. Equality, Diversity and Inclusion - An International Journal, 29(3), 239-254.

Maitland, A. (2000). From women upstarts to start-ups: Women Entrepreneurs. London, UK: Financial Times, p. 20.

Mark, G.M., \& Smith, A.P. (2008). Stress models: A review and suggested new direction. In J. Houdmont \& S. Leka (Eds.), Occupational health psychology (pp. 111-144). Nottingham: Nottingham University Press.

Marsh, H.W., Wen, Z., \& Hau, K.T. (2004). Structural equation models of latent interactions: Evaluation of alternative estimation strategies and indicator construction. Psychological Methods, 9(3), 275-300.

Meredith, V., \& French, S. (1996). Social policy and women in accounting: A crosscultural comparison. International Advances in Economic Research, 2(1), 76-85.

Minnotte, K.L. (2016). Extending the job demands-resources model: Predicting perceived parental success among dual-earners. Journal of Family Issues, 37(3), 416-440.

Moulder, B.C., \& Algina, J. (2002). Comparison of methods for estimating and testing latent variable interactions. Structural Equation Modeling, 9(1), 1-19.

Muthén, L.K., \& Muthén, B.O. (2010). Mplus user's guide (6th edn.). Los Angeles, CA Muthén \& Muthén.

Netemeyer, R.G., Boles, J.S., \& McMurrian, R. (1996). Development and validation of work-family conflict and family-work conflict scales. Journal of Applied Psychology 81(4), 400-410.

Nouri, H., \& Parker, R.J. (2013). Career growth opportunities and employee turnover intentions in public accounting firms. The British Accounting Review, 45(2), 138-148.

Nunnally, J.C. (1978). Psychometric theory. New York: McGraw-Hill.

Prieto, L.L., Soria, M.S., Martinez, I.M., \& Schaufeli, W. (2008). Extension of job demands-resources model in the prediction of burnout and engagement among teachers over time. Psicothema, 20(3), 354-360.

Procopiou Ribeiro, S. (2012). The retention of South African female chartered accountants in public practice. Unpublished master's dissertation, University of Johannesburg, South Africa.

Repenning, N.P. (2000). A dynamic model of resource allocation in multi-project research and development systems. System Dynamics Review, 16(3), 173-212.

Riordan, C.M., Gatewood, R.D., \& Bill, J.B. (1997). Corporate image: Employee reactions and implications for managing corporate social performance. Journal of Business Ethics, 16(4), 401-412.

Roodt, G. (2004). Concept redundancy and contamination in employee commitment research: Current problems and future directions. SA Journal of Industria Psychology, 30(1), 82-90.

Rothmann, S., Barkhuizen, N., \& Tytherleigh, M.Y. (2008). Model of work-related ill health of academic staff in a South African higher education institution. South African Journal of Higher Education, 22(2), 404-422.

Rothmann, S., \& Joubert, J.H.M. (2007). Job demands, job resources, burnout and work engagement of managers at a platinum mine in North West Province. South African Journal of Business Management, 38(3), 49-61.

Rothmann, S., Mostert, K., \& Strydom, M. (2006). A psychometric evaluation of the job demands resources scale in South Africa. SA Journal of Industrial Psychology, 32(4), 76-86.

Rothmann, S., \& Rothmann, S. (2010). Factors associated with employee engagement in South Africa. SA Journal of Industrial Psychology, 36(2), 1-12.

Ruiz Castro, M. (2012). Time demands and gender roles: The case of a big four firm in Mexico. Gender, Work and Organization, 19(5), 532-554.

Sadler, E. (1989). Prospects for the advancement of women chartered accountants in public accounting firms in South Africa. De Ratione Winter, 3, 27-34.

SAICA (South African Institute of Chartered Accountants). (2009). Membership statistics. Retrieved November 24, 2009, from https://www.saica.co.za/Members/ AboutMembers/MembershipStatistics/tabid/502/language/en-ZA/Default.aspx 
Schaufeli, W.B., \& Bakker, A.B. (2003). Utrecht work engagement scale: Test manual, Unpublished manuscript, Department of Psychology, Utrecht University, Utrecht.

Schaufeli, W.B., \& Bakker, A.B. (2004). Job demands, job resources, and their relationship with burnout and engagement: A multi-sample study. Journal of Organizational Behavior, 25(3), 293-315.

Schaufeli, W.B., \& Salanova, M. (2007). Work engagement: An emerging psychological concept and its implications for organizations. In S.W. Gilliland, D.D. Steiner, \& D.P. Skarlicki (Eds.), Research in social issues in management: Managing social and ethical issues in organizations (pp. 135-177). Greenwich, CT: Information Age Publishers.

Snyder, C.R., \& Lopez, S.J. (2002). Handbook of positive psychology. New York: Oxford University Press.

South Africa. (1998). Employment Equity Act, 55. Government Gazette No 19370. Retrieved February 20, 2014, from http://www.labour.gov.za/DOL/downloads/ Retrieved February 20, 2014, from http://www.labour.
legislation/acts/employment-equity/eegazette2015.pdf

Stedham, Y., \& Mitchell, M.C. (1996). Voluntary turnover among non-supervisory casino employees. Journal of Gambling Studies, 12(3), 269-290.

Strümpfer, D.J.W. (1990). Salutogenesis: A new paradigm. South African Journal of Psychology, 20(4), 265-276.

Strümpfer, D.J.W. (2003). Resilience: A stitch that saves nine. South African Journal of Psychology, 33(2), 69-79.

Sverke, M., Hellgren, J., \& Naswall, K. (2002). No security: A meta-analysis and review of job insecurity and its consequences. Journal of Occupational Health Psychology, $7(3), 242-264$
Sweeny, J.T., \& Quirin, J.J. (2009). Accountants as layoff survivors: A research note. Accounting, Organizations and Society, 34(6-7), 787-795.

Tekleab, A.G., \& Quigley, N.R. (2014). Team deep-level diversity, relationship conflict, and team members' affective reactions: A cross-level investigation, Journal of Business Research, 67(3), 394-402.

Van den Berg, H., Manias, D., \& Burger, S. (2008). The influence of job-related factors on work engagement of staff at the University of the Free State. Acta Academia, 40(3), 85-114.

Van Vuuren, T., Klandermans, B., Jacobson, D., \& Hartley, J. (1991). Employees' reactions to job insecurity. In J. Hartley, B. Klandermans, \& T. Van Vuuren, (Eds.) Job insecurity: Coping with jobs at risk (pp. 79-103). London: Sage Publishers.

Vinokur-Kaplan, D., Jayaratne, S., \& Chess, W.A. (1994). Job satisfaction and retention of social workers in public agencies, non-profit agencies, and private practice: The impact of workplace conditions and motivators. Administration in Social Work 18(3), 93-121.

Wiese, L., Rothmann, S., \& Storm, K. (2003). Coping, stress and burnout in the South African police service in Kwazulu-Natal. SA Journal of Industrial Psychology, 29(4), 71-80.

Windsor, C. \& Auyeung, P. (2006). The effect of gender and dependent children on professional accountants' career progression. Critical Perspectives on Accounting, $17(6), 828-844$

Xanthopoulou, D., Bakker, A.B., Demerouti, E., \& Schaufeli, W.B. (2009). Reciprocal relationships between job resources, personal resources, and work engagement. Journal of Vocational Behavior, 74(3), 235-244. 